\title{
Thin layers and camouflage: hidden Pseudo-nitzschia spp. (Bacillariophyceae) populations in a fjord in the San Juan Islands, Washington, USA
}

\author{
J. E. B. Rines ${ }^{1, *}$, P. L. Donaghay ${ }^{1}$, M. M. Dekshenieks ${ }^{2}$, J. M. Sullivan ${ }^{1}$, \\ M. S. Twardowski ${ }^{3}$ \\ ${ }^{1}$ Graduate School of Oceanography, University of Rhode Island, South Ferry Road, Narragansett, Rhode Island 02882-1197, USA \\ ${ }^{2}$ Ocean Sciences Department, University of California Santa Cruz, Santa Cruz, California 95064, USA \\ ${ }^{3}$ Department of Research, Western Environmental Technology Laboratories, Inc., 165 Dean Knauss Drive, Narragansett, \\ Rhode Island 02882, USA
}

\begin{abstract}
Two sets of observations were made on the distribution of Pseudo-nitzschia taxa in a fjord in the San Juan Islands, Washington, USA. From May 21 to 31, 1996, we observed the spatiotemporal distribution of a dense bloom of $P$. fraudulenta. Microscopic observations of live material were compared to physical-optical water-column structure, currents and wind. At the start of the study, dense concentrations of Pseudo-nitzschia spp. were observed directly at the surface. Optical profiles indicated that most cells were concentrated in a thin layer at $\sim 5 \mathrm{~m}$ depth, which appeared to be contiguous throughout the sound. Several days later, sustained winds forced a plume of lighter water over the surface of the sound, displacing the original water mass, with its entrained flora, to depth. The resulting near-bottom thin layer persisted for several days, and contained $>10^{6}$ Pseudonitzschia spp. cells $\mathrm{l}^{-1}$. Microscopic examination of live cells from the deep layer revealed that colonies were alive and motile. In 1996 and again in 1998, we observed P. pseudodelicatissima living within colonies of Chaetoceros socialis. Water-column thin layers, near-bottom thin layers and populations of Pseudo-nitzschia spp. within C. socialis colonies could easily escape detection by routine monitoring procedures, and may be a potential source of unexplained toxicity events.
\end{abstract}

KEY WORDS: Pseudo-nitzschia $\cdot$ Chaetoceros socialis $\cdot$ Thin layers $\cdot$ Physical forcing

\section{INTRODUCTION}

Pseudo-nitzschia H. Peragallo in H. \& M. Peragallo is a cosmopolitan genus of marine planktonic diatoms comprising approximately 20 species (Hasle 1994, Hasle \& Fryxell 1995, Hasle \& Syvertsen 1996). Although sometimes ranked as a subgeneric section of Nitzschia Hassall, the recent trend has been to recognize these taxa at the generic level on the basis of ultrastructural and ecological features (Hasle 1994, Hasle et al. 1996).

*E-mail: jrines@gso.uri.edu
The systematics and ecology of Pseudo-nitzschia spp. are of special interest, since several species produce the neurotoxin domoic acid (reviewed by Bates et al. 1998, Bates 2001). Filter-feeding shellfish and finfish (e.g. anchovies) retain the toxin, which is then passed along the food chain and can result in amnesic shellfish poisoning (ASP) or domoic acid poisoning (DAP) of humans, sea birds and marine mammals (Bates et al. 1998, Scholin et al. 2000). In addition to its impact on the ecosystem, ASP has resulted in both human death and permanent neurological impairment (Bates et al. 1989, Bird \& Wright 1989). Therefore, since some Pseudo-nitzschia species can cause harmful algal 
blooms (HABs), there is particular interest in understanding the population dynamics of both the genus as a whole, and of its individual species.

In order to develop numerical models which forecast blooms of Pseudo-nitzschia spp., and predict their toxicity, risk to public health, as well as economic and ecosystem impacts, we need to understand the factors that control species-specific distributions of phytoplankton in space and time. To date, numerous autecological studies have been conducted on Pseudonitzschia spp., summarizing specific responses to nutrients, temperature and salinity. However, very few studies have investigated the effects of light levels on growth dynamics (reviewed by Bates 1998 and Bates et al. 1998). Field studies have attempted to correlate the presence of blooms to regional conditions (e.g. prolonged dry sunny periods followed by rain), upwelling events, and global climatic patterns (e.g. El Niño Southern Oscillation). Many plausible scenarios have been proposed, yet despite this large body of information, there seems to have been little real progress in establishing clear patterns of the environmental conditions that will lead to a bloom, or in consistently identifying the source, or seed population which initiates a bloom.

Additionally, there have been numerous domoic acid events for which the source of the toxin could not be found. Horner et al. (1997) and Bates et al. (1998) reviewed reports of contaminated razor clams and Dungeness crabs from Pacific Northwest waters, sea scallops from Georges/Browns Bank in the North Atlantic, and cultured mussels from Newfoundland. In each case, the source of domoic acid was not determined. Since Pseudo-nitzschia spp. form needle-like cells approximately 50 to $150 \mu \mathrm{m}$ in length, with colonies sometimes exceeding $1 \mathrm{~cm}$, they are an obvious member of the net phytoplankton, unlikely to be overlooked. Blooms must reach substantial concentrations $\left(>10^{5}\right.$ cells $\mathrm{l}^{-1}$ ) before shellfish accumulate enough toxin to result in closure of a fishery. Therefore, a Pseudonitzschia spp. bloom should be easy to detect by microscopic examination of the net-plankton flora. That it was not observed in the above cases implies that other kinds of organisms can produce domoic acid, that the ecology of Pseudo-nitzschia species may be more complex than predicted by autecological studies, or that the sampling strategy failed to locate the cells within the water column.

In addition to factors which regulate cell numbers or density of a bloom (in growth and loss terms), several other kinds of information may be important in understanding phytoplankton ecology and the dynamics of HABs at the species-specific level. Examples include behavior of the organism, the role of life-history stages, large and small-scale biological-physical interactions, and the relative location of the population of toxic algae and the 'target' organism (e.g. filter-feeding fishes and shellfish) within the water column (Donaghay \& Osborn 1997). Formation of thin layers of harmful algae-structures only centimeters to a few meters in vertical extent, with horizontal scales on the order of kilometers (Bjørnsen \& Nielsen 1991, Donaghay et al. 1992, Cowles \& Donaghay 1998, Dekshenieks et al. 2001) - may also be important, because the dynamics and impacts of a HAB population concentrated into a thin layer may be very different from that of a population spread throughout the water column.

We had the opportunity to make observations on thin layers of Pseudo-nitzschia fraudulenta (Cleve) Hasle and on behavioral/life history aspects of $P$. pseudodelicatissima (Hasle) Hasle during an ongoing oceanographic investigation on the coupling of physical, optical and biological processes in coastal waters. This study took place in East Sound, a small fjord in the San Juan Islands, in the southern part of the Strait of Georgia on the US-Canadian border. The genus Pseudonitzschia is common in East Sound, as it is throughout the Pacific Northwest region (Gran \& Angst 1931, Forbes \& Denman 1991, Taylor et al. 1994, Taylor \& Haigh 1996, Horner et al. 1997, Trainer et al. 1998a).

\section{MATERIALS AND METHODS}

Field site. East Sound is a fjord on the coast of Orcas Island, Washington, USA (Fig. 1). It is oriented NW to $\mathrm{SE}$, and is $\sim 12 \mathrm{~km}$ long and 1 to $2.5 \mathrm{~km}$ wide. For most of its extent, it is $\sim 30 \mathrm{~m}$ deep, with a tidal range from 0.3 to $3.5 \mathrm{~m}$. Circulation with contiguous waters is partially obstructed by a sill, which extends approximately half way across the western side at the mouth. Circulation within East Sound is driven by local winds, tides and bathymetry (Rattray 1964). It is also strongly influenced by regional-scale physical forcing events in the southern part of the Strait of Georgia, which affect the distribution of water mass types throughout the San Juan archipelago (Thomson 1981). Since Orcas Island has no major rivers, the primary source of freshwater to East Sound is the Fraser River, located $\sim 23 \mathrm{~km}$ to the north, on the Canadian mainland. In early summer, after the mountain snows have melted, river outflow is at its maximum (Thomson 1981). During periods of strong winds from the north, the Fraser River plume is advected southward and can reach the mouth of East Sound. The warmer, fresher water from the Strait of Georgia is less dense and overrides the higher salinity water already present in East Sound, displacing it to depth (Twardowski \& Donaghay 2001). This sequence of events is a common occurrence in this system. 
Fig. 1. Map of the San Juan Islands, with detail of East Sound. (•) Stn 2 in the Speiden Channel (from Gran \& Thompson 1930)

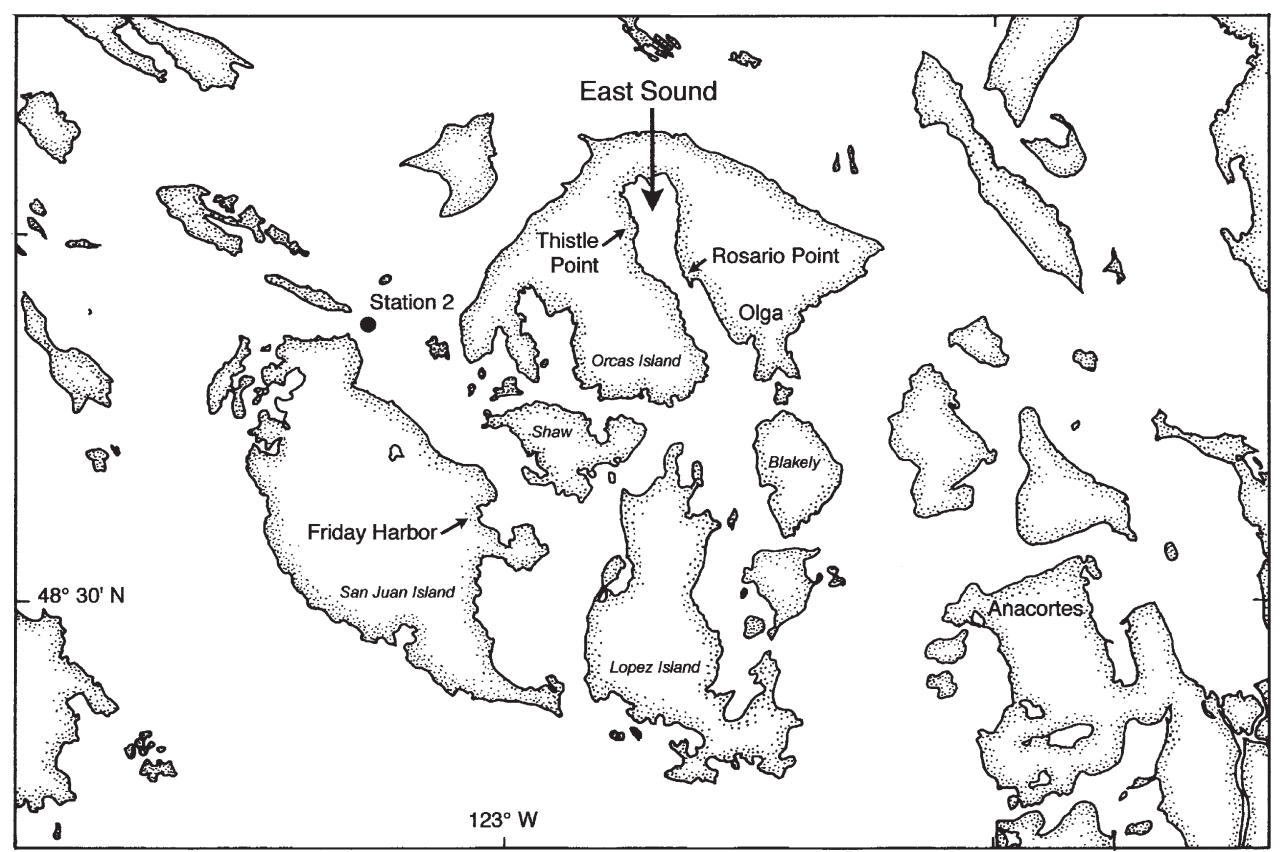

The first field study took place from May 21 to June 1, 1996; additional observations were made in May and June 1998.

Phytoplankton sampling. The phytoplankton was sampled in 2 years.

May and June 1996: On May 21 and 23, dense concentrations of phytoplankton were visible at the surface near the mouth of the sound, and were collected by bucket. On May 25, 26 and 27, samples integrating the upper $10 \mathrm{~m}$ of the water column were collected via vertical net tows (64 $\mu$ mesh). On May 28 and 30 and June 1, samples were collected from discrete depths between 0 and $30 \mathrm{~m}$ utilizing a siphon tube attached to the high-resolution profiling system, as detailed by Donaghay et al. (1992). All samples were immediately examined live, aboard ship, with phase-contrast microscopy. Archival images of each live sample were recorded on videotape. Whole water samples from May 28 and 30 and June 1 were preserved with formalin for subsequent enumeration of Pseudo-nitzschia spp. cells from inside and outside optical thin layers (described below). One ml aliquots were counted in a Sedgwick-Rafter chamber.

May and June 1998: Observations on the association between Chaetoceros socialis and Pseudo-nitzschia pseudodelicatissima were made in the field over the course of several weeks, using exclusively live material collected by surface bucket or subsurface siphon. Upon collection, all samples were immediately examined live, aboard ship, using phase contrast microscopy. Archival images of each live sample were recorded on $35 \mathrm{~mm}$ film and videotape, documenting the association in live material throughout the period of study. Additionally, whole-water samples were preserved with formalin and returned to the laboratory. C. socialis and $P$. pseudodelicatissima cells were subsequently enumerated in a Sedgwick-Rafter chamber.

Permanent slides and electron microscopy. Net tows from May 25, 1996, and June 24, 1998, were prepared for species-level identification of Pseudo-nitzschia. Material for permanent slides was desalinated by dialysis through $15 \mu \mathrm{m}$ Nitex, dried on coverslips, heat-oxidized and mounted in Hyrax. Material for electron microscopy was desalinated, oxidized in $\mathrm{KMnO}_{4}$, cleared with $\mathrm{HCl}$ (Simonsen 1974), rinsed in sterile, filtered, deionized water, and mounted on Formvar-coated grids. They were examined on a JEOL 1200EX STEM. Identifications were based on morphometric data and taxonomic descriptions in Hasle \& Syvertsen (1996) and Hasle et al. (1996).

Winds and tides. Wind velocity and tidal height in East Sound were recorded for the duration of the study (Fig. 2). Wind speed and direction were recorded at a weather station (Davis Instruments) located on Thistle Point (Fig. 1). Tides were measured near Rosario Point with an Endeco Model 1029 tide gauge.

Fine-scale physical, chemical and optical structure. The physical, chemical and optical structure of the water column were simultaneously profiled at centimeter scales. Physical and chemical structure were measured by a Seabird SBE 911-plus CTD equipped with a ducted flow conductivity cell, a fast-response thermistor, a combination $\mathrm{pH} / \mathrm{eH}$ sensor, an oxygen 


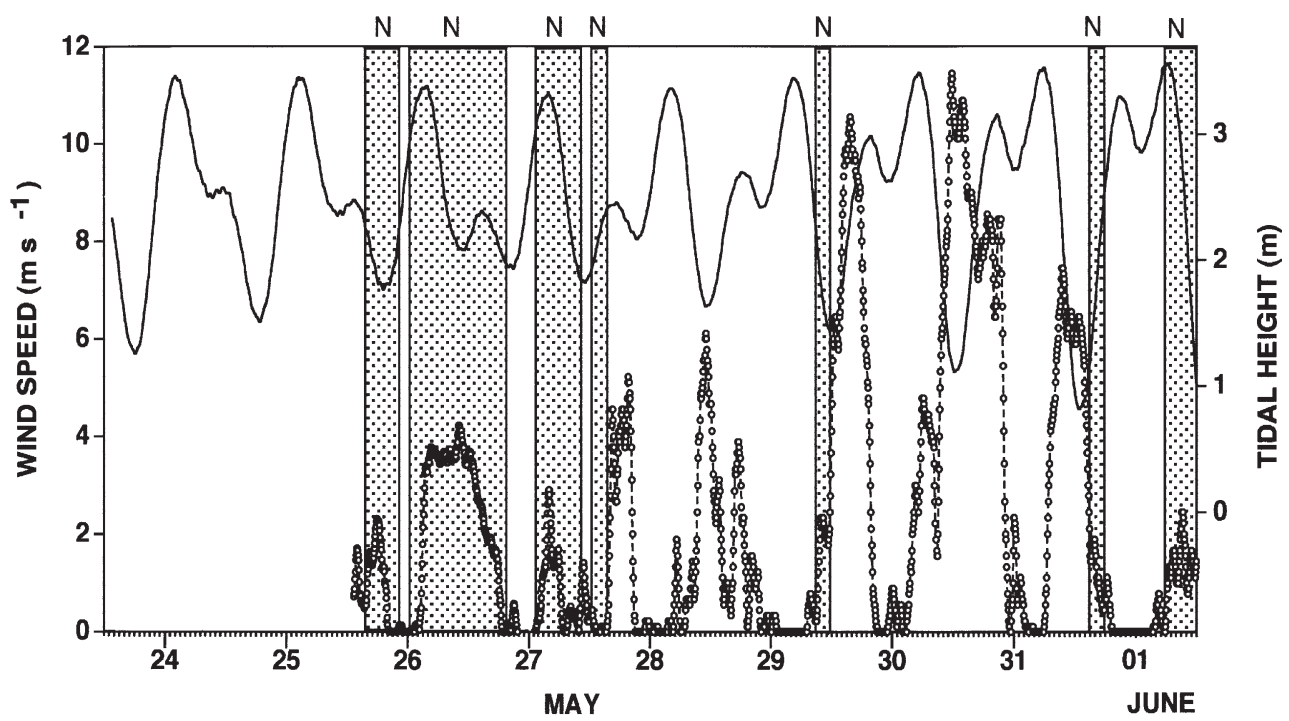

Fig. 2. Wind speed and direction and tidal height in East Sound for study period. (-o-) Average wind speed (5 min averages); stippling: periods of north winds; line: tidal height sensor, and a Digiquartz pressure sensor capable of measuring depth changes of $1 \mathrm{~cm}$. The optical structure was measured with WET Labs (Philomath, OR) absorption and attenuation meters (an ac-9 and aa-9). An ac-9 measures spectral absorption and attenuation at 9 wavelengths between 412 and $750 \mathrm{~nm}$. The aa- 9 was a modified ac-9, with the normal attenuation channel replaced by a second absorption channel. Using the methods described by Twardowski et al. (1999) and Twardowski \& Donaghay (2001), the spectral absorption by dissolved substances was measured with an aa-9 equipped with a $0.2 \mu \mathrm{m}$ filter. At the same time, total spectral absorption and attenuation by dissolved and particulate material was measured with the ac-9. Spectral absorption by particulate material was then calculated as the difference between the two. Particulate absorption at $440 \mathrm{~nm}\left(\mathrm{a}_{\mathrm{p}} 440\right)$, a primary wavelength of absorption by chlorophyll $a$, was used as an indicator of phytoplankton biomass. Vertical profiles of photosynthetically available radiation (PAR) were obtained with a Biospherical Instruments (San Diego, CA) PUV-500. Current magnitude and direction were continuously measured at $50 \mathrm{~cm}$ resolution with a downward-looking RDI $1200 \mathrm{kHz}$ Acoustic Doppler Current Profiler (ADCP). Reported current velocities are based on 10 min averages of the ADCP data, which were taken at the same time as each of the profiles.

\section{OBSERVATIONS}

\section{Taxonomy}

In 1996, 3 species of Pseudo-nitzschia were identified from East Sound. Two occurred as planktonic colonies living freely within the water column (Fig. 3a), and the third upon/within the spherical colonies of Chaetoceros socialis Lauder (Fig. 3b). In 1998, the C. socialis-Pseudo-nitzschia sp. association was observed again, this time in greater abundance, and persisting over the course of several weeks. Both single cells and colonies were seen within the C. socialis matrix. Using electron microscopy, the dominant taxon in 1996 material was identified as $P$. fraudulenta (Cleve) Hasle (Fig. 4a); small amounts of $P$. pungens (Grunow ex Cleve) Hasle were also present (Fig. 4b). The taxon living in association with $C$. socialis was identified as $P$. pseudodelicatissima (Hasle) Hasle (Fig. 4c,d).

\section{Thin layers of Pseudo-nitzschia fraudulenta}

The 1996 Pseudo-nitzschia fraudulenta bloom was observed over a period of $12 \mathrm{~d}$ in conjunction with physically-forced hydrographic events in East Sound. At the start of the field study on May 21, weather conditions were sunny and very calm. Dense concentrations of phytoplankton were present at the sea surface near the sill. Ship-board microscopic examination of live material showed the sample to be dominated by needle-like colonies of Pseudo-nitzschia spp., Rhizosolenia hebetata forma semispina (Hensen) Gran and $R$. pungens Cleve-Euler. Also present were various Chaetoceros species, Odontella longicruris (Greville) Hoban, Eucampia zodiacus Ehrenberg, Asterionellopsis glacialis (Castracane) Round, Alexandrium catenella (Whedon \& Kofoid) Balech and Protoperidinium spp. The weather pattern continued, and on May 23 the bloom was still present near the sill. Massive numbers of Pseudo-nitzschia spp. colonies $>1 \mathrm{~cm}$ in length were visible directly at the surface. 


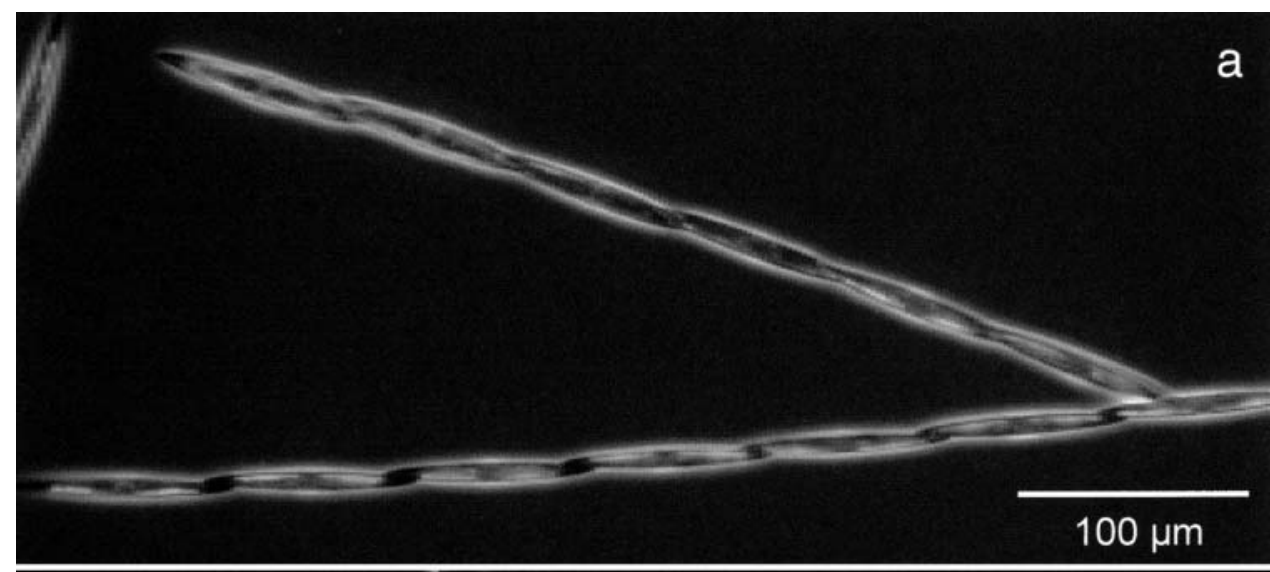

Fig. 3. Light micrographs (phase-contrast) of live diatom material. (a) Pseudonitzschia fraudulenta, showing stepped mode of colony formation. (b) P. pseudodelicatissima, showing single cells and short chains living within and upon a colony of Chaetoceros socialis, photographed in the field; this is a relatively small colony of $C$. socialis, collected early in the bloom; all cells of both species are highly pigmented and the assemblage is free of debris and other detritus

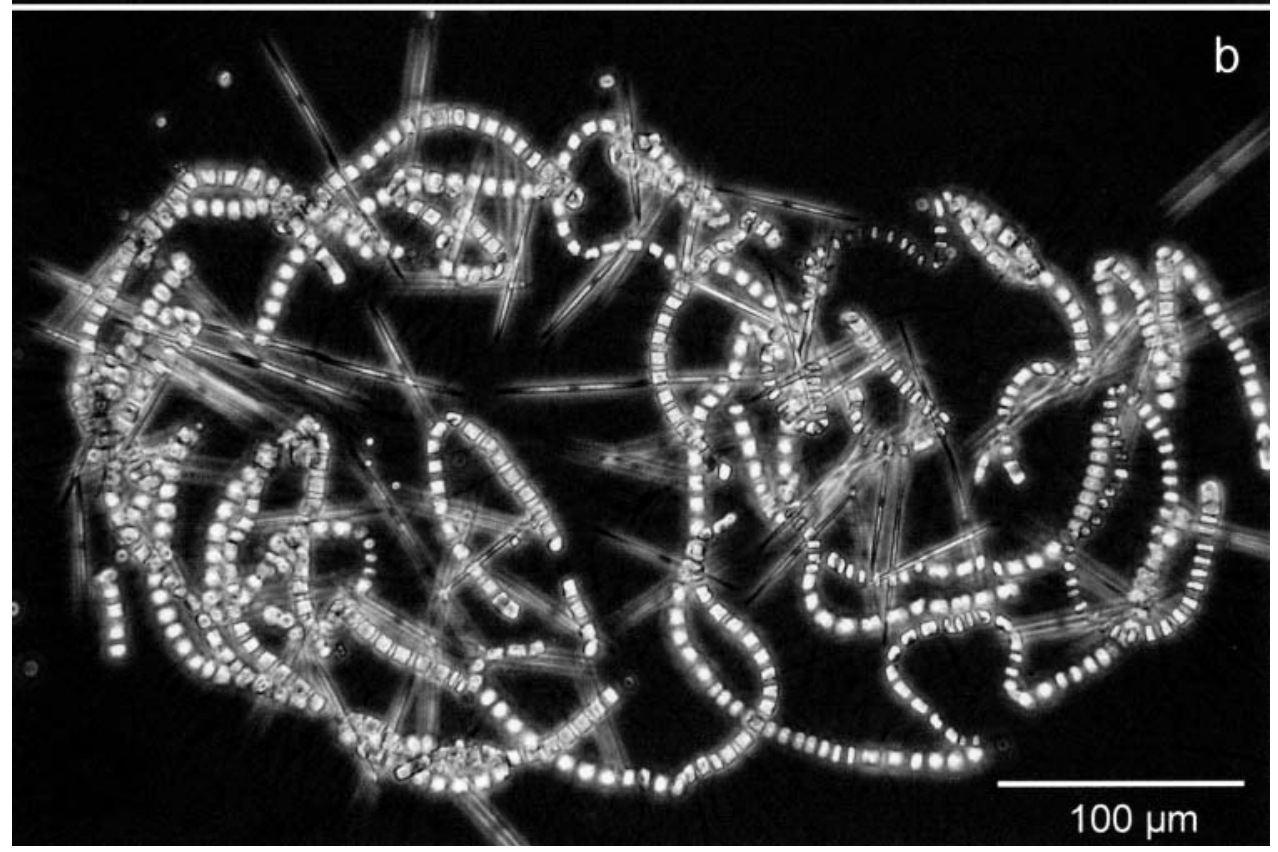

Profiles of physical and optical structure (Fig. 5) (which start about $1 \mathrm{~m}$ below the surface) showed that concentrations of phytoplankton (inferred from $\mathrm{a}_{\mathrm{p}} 440$ measurements) were not only high near the surface ( 1 to $4 \mathrm{~m}$ ), but increased by a factor of 4 in a thin layer located near the bottom of the primary pycnocline at about $5 \mathrm{~m}$ depth (Fig. 5j). Physical and optical profiles at 4 additional stations along the longitudinal axis of the sound (Fig. 5k) indicated that a similar thin layer was located near the base of the primary pycnocline throughout the sound (Fig. 5f,i). Although $\mathrm{a}_{\mathrm{p}} 440$ at the surface declined by a factor of 2 along the axis of the sound (compare Fig. 5j,f), the maximum $\mathrm{a}_{\mathrm{p}} 440$ increased by more than $50 \%$ within the thin layer, reaching peak values of $6.5 \mathrm{~m}^{-1}$ (Fig. 5f) in the upper sound. This was more than 12 times the surface absorption at this northern sound station, and 6 times greater than near-surface absorption at the mouth of the sound.
These values were some of the highest we have ever observed in coastal waters, and they suggest that intense concentrations of phytoplankton were present.

On May 25, physical-optical profiles were taken at 9 stations, transecting north to south along the axis of the sound, and ending outside the sill in the channel between Orcas, Blakely, Lopez and Shaw Islands (Fig. 6). Temperature and salinity data indicated that stratification extended almost to the surface at all stations south of Rosario Point (mid-sound), with a gradual warming and freshening of surface waters along this segment of the transect (Fig. 6d-i). However, north of Rosario Point, surface waters were relatively cooler and saltier, and the surface mixed layer thickened to nearly $12 \mathrm{~m}$ at the northernmost station in the sound. Optical profiles at each station showed a low $\left(\mathrm{a}_{\mathrm{p}} 440 \sim 0.5 \mathrm{~m}^{-1}\right)$, broad peak in particulate absorption outside the sound (Fig. 6r) that became thinner and 


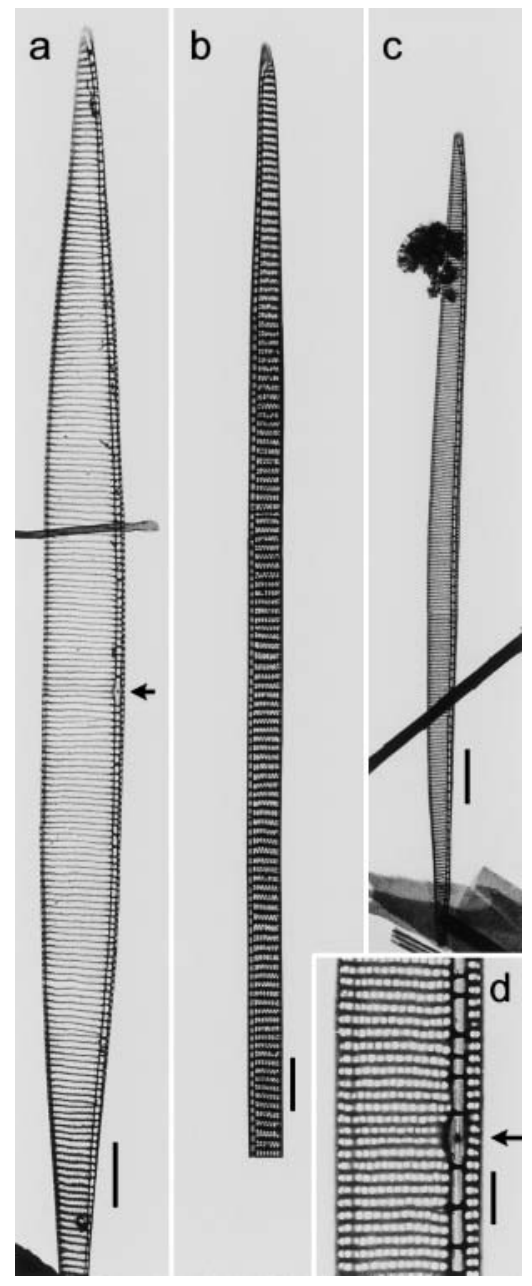

Fig. 4. Transmission electron micrographs. (a) Pseudo-nitzschia fraudulenta; characteristics: central interspace present (arrow), transapical axis $6 \mu \mathrm{m}$, apical axis $\sim 110 \mu \mathrm{m}$, 21 striae and 19 fibulae within $10 \mu \mathrm{m}, 2$ rows of pores. (b) P. pungens; characteristics: central interspace absent, transapical axis $3.5 \mu \mathrm{m}, 11$ striae and 12 fibulae within $10 \mu \mathrm{m}, 2$ rows of pores. (c,d) P. pseudodelicatissima; characteristics: central interspace present (arrow), transapical axis $\sim 3 \mu \mathrm{m}$, apical axis $\sim 80 \mu \mathrm{m}, 34$ to 40 striae and 14 to 16 fibulae in $10 \mu \mathrm{m}$, single row of pores. Not revealed by Electron microscopy: overlap of cells in chains $1 / 9$ to $1 / 10$ of cell length. Scale bars in (a) (b) (c) $=5 \mu \mathrm{m},(\mathrm{d})=1 \mu \mathrm{m}$

more concentrated progressing northward along the axis of the sound, reaching maximum values 20 -fold higher at mid-sound $\left(\mathrm{a}_{\mathrm{p}} 440 \sim 4.0 \mathrm{~m}^{-1}\right.$ : Fig. $\left.6 \mathrm{~m}\right)$. At the northern end, peak absorption values decreased, and the peak broadened (Fig. 6j-1). Collectively, this data suggests that a strong bloom was still in progress along the entire axis of the sound.

Vertical net tows integrating the top $10 \mathrm{~m}$ of the water column at each station (encompassing most subsurface layers) showed that a similar flora was present in the upper $10 \mathrm{~m}$ throughout the sound, comprising Pseudo-nitzschia spp., Rhizosolenia hebetata forma semispina, R. pungens, Odontella longicruris and Thalassionema nitzschioides (Grunow) Grunow ex Hustedt. By cell number, Pseudo-nitzschia spp. accounted for $\sim 50$ to $55 \%$ of the net phytoplankton at the northern stations, $\sim 40 \%$ in the mid-sound, declining to $\sim 25 \%$ near the sill. This pattern of dominance of Pseudo-nitzschia spp. in the integrated tows strongly supports the hypothesis that the thin layer at the base of the pycnocline was a subsurface bloom dominated by this taxon.

On May 26, a $5 \mathrm{~m} \mathrm{~s}^{-1}$ wind developed from the north, with gusts reaching 9 to $12 \mathrm{~m} \mathrm{~s}^{-1}$. Winds were sustained for approximately $16 \mathrm{~h}$ (Fig. 2), and triggered the advection of the Fraser River buoyant plume into East Sound. On May 27, salinity at the mouth of the sound had dropped from 29.2 to $27.0 \mathrm{psu}$. A thick lens of lower-salinity water extended from the mouth to Rosario Point. It thinned considerably toward the more northern part of the sound, indicating that a new, lowsalinity water mass was flowing inward at the surface. Velocity profiles confirmed this, showing that surface waters were moving into the sound at $35 \mathrm{~cm} \mathrm{~s}^{-1}$, and deep waters (15 to $25 \mathrm{~m}$ ) were moving out of the sound at 15 to $20 \mathrm{~cm} \mathrm{~s}^{-1}$. Optical profiles showed a dramatic drop in particulate absorption at the surface, with most $\mathrm{a}_{\mathrm{p}} 440$ values being less than $1 \mathrm{~m}^{-1}$. Although thin layers were still evident at some stations near mid-sound (Fig. $7 \mathrm{c}, \mathrm{d}$ ), their absorption signals were reduced, with peak values only 1.5 to 2.9 times greater than the particulate absorption of the surrounding water. The patterns of large-scale spatial coherence seen on May 23 (Fig. 5) and May 25 (Fig. 6) had clearly disappeared on May 27 (Fig. 7).

Representative profiles from each day of sampling were used to evaluate the sequential changes in salinity and optical structure from May 23 to 31 (Fig. 8). On May 28, profiles from the northern part of the sound (Fig. 8e) revealed the presence of a broad $a_{p} 440$ maximum at mid-depths, and a thin layer of $\mathrm{a}_{\mathrm{p}} 440$ at 24 to $24.5 \mathrm{~m}$, near the base of the primary pycnocline (Fig. 8e). Prior to this date, near-bottom thin layers had not been observed. Water siphoned from within the deep layer ( 24 to $24.5 \mathrm{~m}$ ) was immediately examined live, under the microscope. The $>20 \mu \mathrm{m}$ phytoplankton was dominated by long, needle-like colonies of Pseudonitzschia fraudulenta, which appeared both healthy and free of surface bacteria. There were very few empty frustules, and many colonies were motile. They were not aggregated into flocs of marine snow. Subsequent enumeration of a preserved sample yielded a density of $2 \times 10^{6}$ Pseudo-nitzschia spp. cells $\mathrm{l}^{-1}$, comprising $86 \%$ of the $>20 \mu \mathrm{m}$ phytoplankton by number. Other taxa present at this depth included Rhizosolenia hebetata forma semispina, Thalassionema nitzschioides, Odontella longicruris and Asterionellopsis glacialis, 


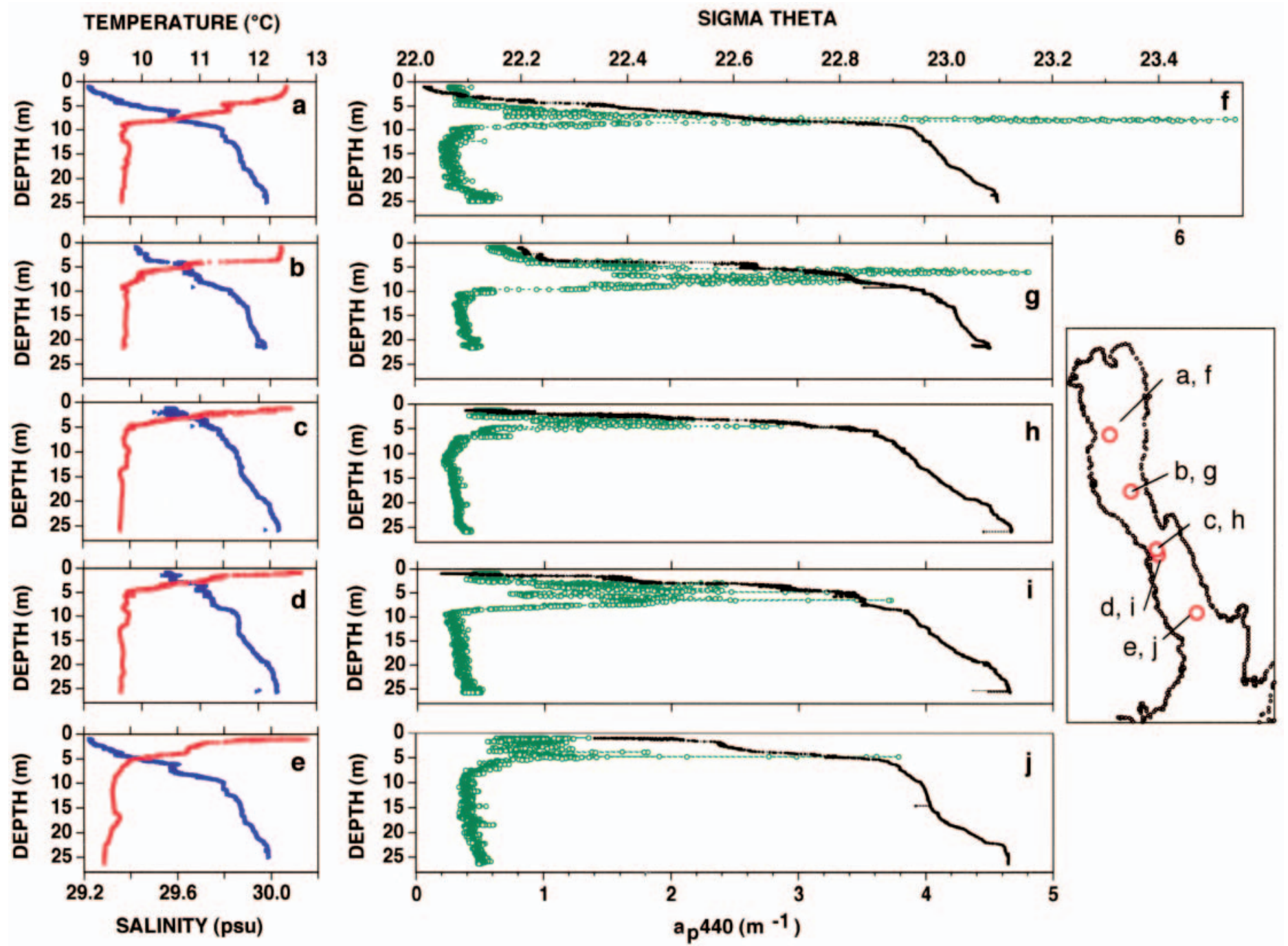

Fig. 5. Initial physical and optical structure in East Sound on May 23, 1996. (a-e) Temperature (red) and salinity (blue) profiles; (f-j) particulate absorption, $a_{p} 440$ (green) and sigma theta (black) profiles. Inset map shows stations where samples were collected

but unlike the Pseudo-nitzschia spp., these appeared to be in poor health. At a depth of 20.5 to $21 \mathrm{~m}$, just above the layer, concentrations dropped to $2 \times 10^{5}$ cells $\mathrm{l}^{-1}$ and the relative dominance of Pseudo-nitzschia spp. declined to $63 \%$ of the cell count.

A time series of physical and optical profiles collected on May 29 revealed a similar near bottom phytoplankton layer at a mid-sound station (represented by Fig. 8f). Particulate absorption $\left(a_{p} 440\right)$ in this layer was lower than at the upper-sound station on May 28 ( 0.75 vs $\left.1.5 \mathrm{~m}^{-1}\right)$, but was also reduced proportionally at shallower depths $\left(a_{p} 440\right.$ values just above the thin layer dropped from 0.5 to $0.2 \mathrm{~m}^{-1}$ ). Therefore, this layer remained the dominant fine-scale feature of the water column. It was detected in all 7 profiles collected at this station over a $6 \mathrm{~h}$ period, and was always located near the base of the primary pycnocline.
The near-bottom thin layer was still present $2 \mathrm{~d}$ later (May 31), with only a slight decline in $\mathrm{a}_{\mathrm{p}} 440$, from 0.78 to $0.68 \mathrm{~m}^{-1}$ (Fig. 8g). Siphon samples taken from within the layer indicated that it was still dominated by Pseudo-nitzschia spp., with concentrations at $26.9 \mathrm{~m}$ reaching $8 \times 10^{5}$ cells l$^{-1}$ (94\% of $>20 \mu \mathrm{m}$ phytoplankton). Colonies were very long (30+ cells) and appeared free of surface bacteria or other detritus. Colonies were separate from each other, and were not tangled into aggregates. There were very few dead (empty) cells.

On May 31, a second thin layer was detected at 3 to $4 \mathrm{~m}$ at the mid-sound station (Fig. 8g). It persisted throughout the $24 \mathrm{~h}$ sampling period. Phytoplankton siphoned from within this layer was dominated by Odontella longicruris, Thalassiosira spp., Thalassionema nitzschioides and Asterionellopsis glacialis. Pseudo-nitzschia spp. concentrations in samples from 

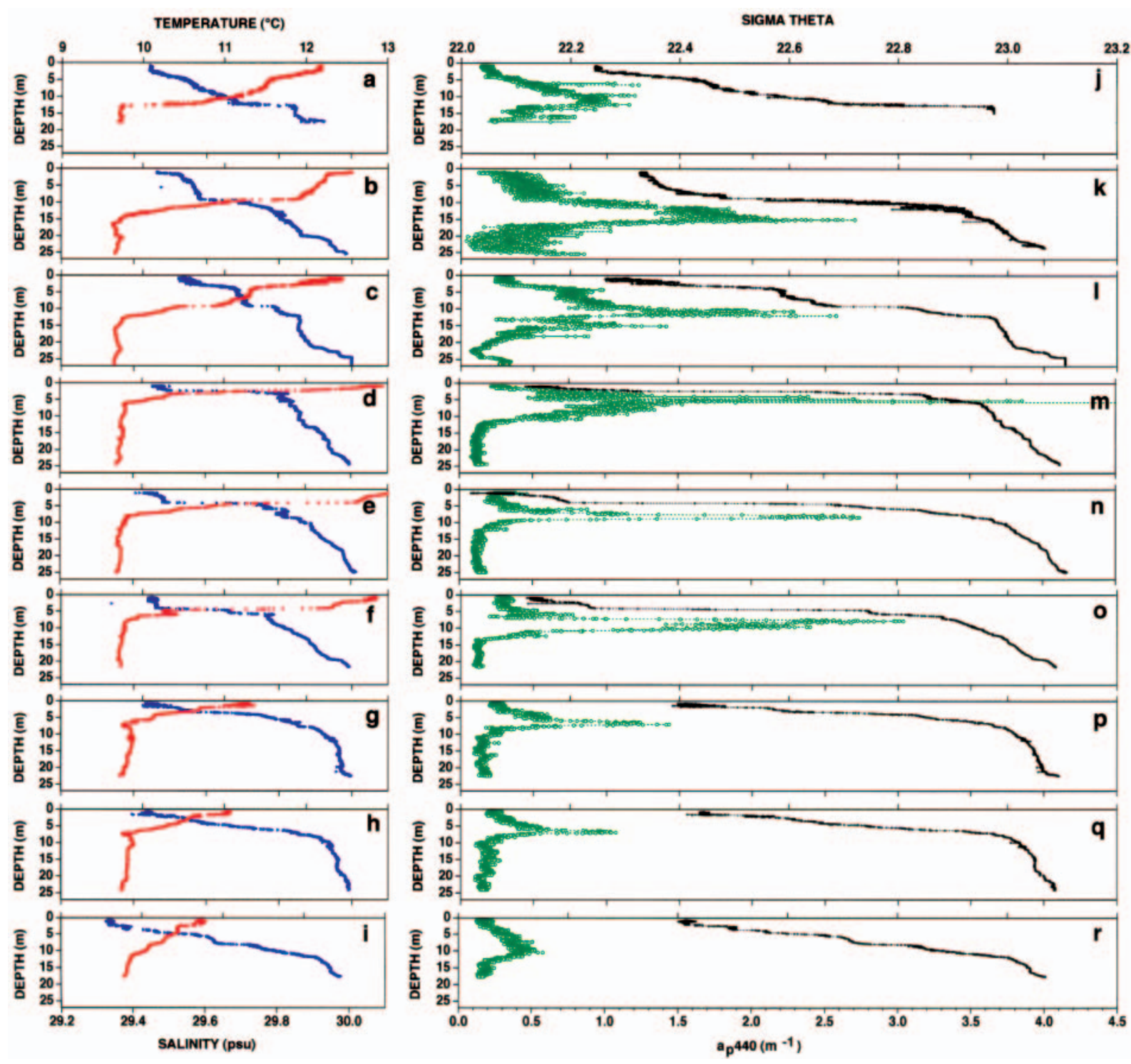

Fig. 6. Physical and optical structure in East Sound on May 25, 1996, prior to arrival of Fraser River plume. (a-i) temperature (red) and salinity (blue) profiles; $(\mathrm{j}-\mathrm{r}) \mathrm{a}_{\mathrm{p}} 440 \mathrm{~nm}$ (green) and sigma theta (black) profiles. (Stns q and r were outside the sound)

the upper water column $(2.5,4.3,5.2$ and $7.5 \mathrm{~m})$ ranged from 0 to $5 \times 10^{4}$ cells $1^{-1}$, comprising only 0 to $7 \%$ of the $>20 \mu \mathrm{m}$ phytoplankton population. Thus, the thin layer situated at 3 to $4 \mathrm{~m}$ had a very different composition and history from the near-bottom layer (see Twardowski \& Donaghay 2001 for discussion of the evolution of the 3 to $4 \mathrm{~m}$ layer).

\section{Biological-physical interactions}

The effect of regional-scale physical forcing events on the vertical distribution of Pseudo-nitzschia spp. in East Sound was examined by comparing the salinity structure of the water column to the location of thin layers of high particulate absorption on each of the $7 \mathrm{~d}$ of profiles (Fig. 8). From May 23 to 25, before the buoyant plume reached East Sound, thin layers were observed in the upper water column in a water mass with a salinity of $\sim 29.8$ psu (Fig. 8a-c). This relationship was consistent along the axis of the sound, suggesting that a single, coherent layer was present throughout the area. No near-bottom layers were observed during this period (Fig. 8a-c).

When the Fraser River plume first began to flow across the surface of the sound on May 27, it displaced the 29.8 salinity surface (with the entrained phytoplankton) downward to $\sim 13 \mathrm{~m}$ (Fig. 8d). Near-bottom layers were found only after a thick lens of plume water covered much of East Sound. Like the thin layer 

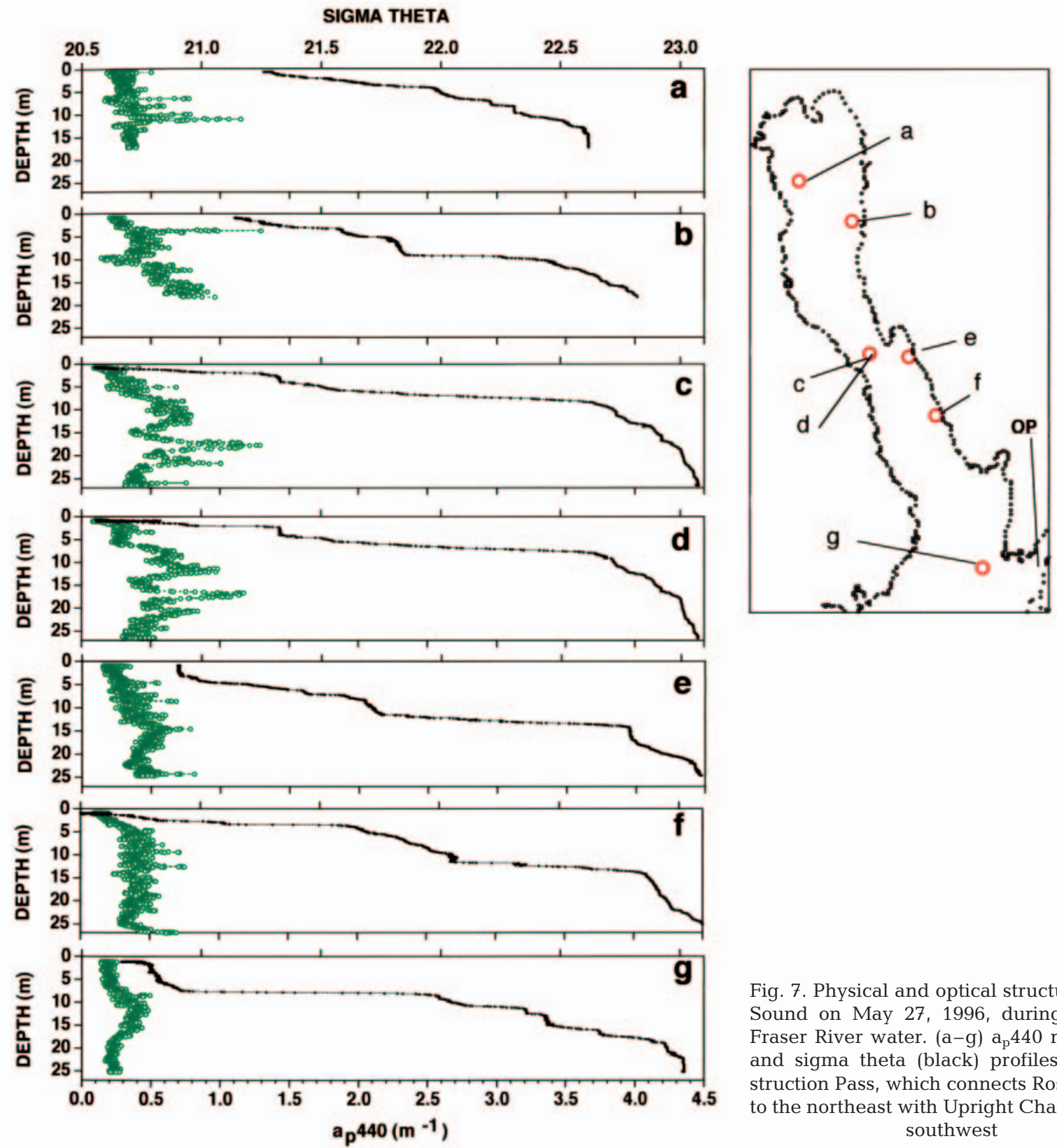

Fig. 7. Physical and optical structure in East Sound on May 27, 1996, during influx of Fraser River water. $(\mathrm{a}-\mathrm{g}) \mathrm{a}_{\mathrm{p}} 440 \mathrm{~nm}$ (green) and sigma theta (black) profiles. OP: Obstruction Pass, which connects Rosario Strait to the northeast with Upright Channel to the southwest

of the upper water column, the near-bottom, Pseudonitzschia-dominated thin layer observed on May 28, 29 and 31 was also located in water with a salinity of 29.8 psu (Fig. 8e-g). In contrast, the upper water-column layer observed on May 31 was located in Fraser River plume water, identified by its different salinity signature of 27.4 psu (Fig. 8g).

\section{Chaetoceros socialis-Pseudo-nitzschia pseudodelicatissima association}

In 1996, spherical colonies of Chaetoceros socialis were first observed with Pseudo-nitzschia pseudodeli- catissima living upon/within them. In May and June of 1998, C. socialis bloomed in East Sound, reaching densities of $\sim 8 \times 10^{6}$ cells $~^{-1}$. Careful examination of live, gently collected material showed that in many samples, virtually $100 \%$ of the C. socialis colonies were colonized by P. pseudodelicatissima, (Fig. 3b), occurring both as single cells, and as short chains of up to about 5 cells. The C. socialis-P. pseudodelicatissima associations were generally free of entrained debris, other phytoplankton and heterotrophic flagellates (Fig. 3b), and were not aggregated into flocs of marine snow. Different sizes of $P$. pseudodelicatissima cells were noted (apical length of 48 to $102 \mu \mathrm{m}$ ). The association persisted throughout the $3 \mathrm{wk}$ we spent in the 


\section{SALINITY (psu)}

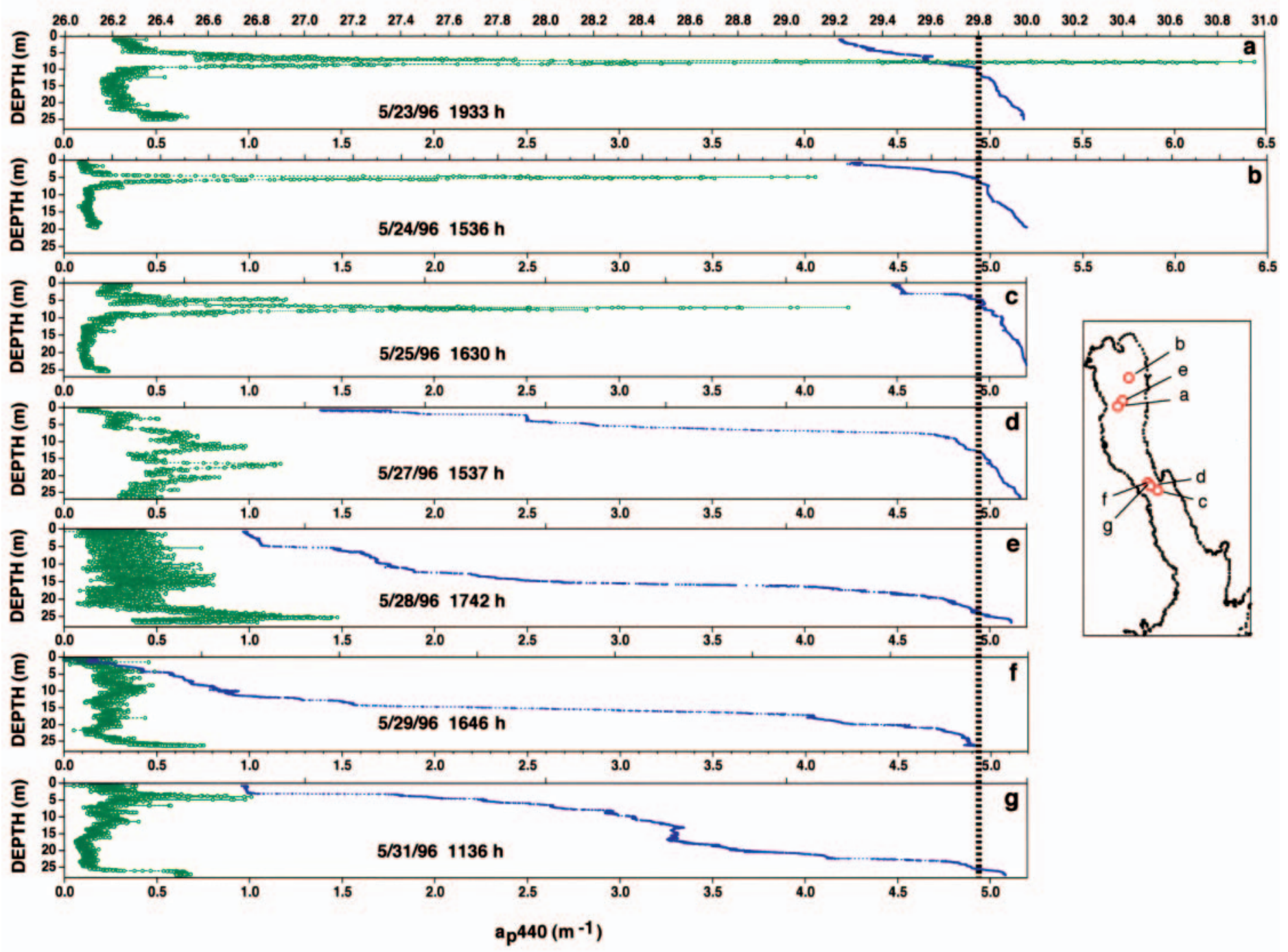

Fig. 8. Salinity structure associated with thin optical layers in East Sound, May 23 to 31, 1996. (a-g) Individual profiles of salinity (blue) and $\mathrm{a}_{\mathrm{p}} 440$ (green); each panel is labeled with date (mo/d/yr) and time of profile. Vertical dashed line traces 29.8 psu across all graphs

field. Only near the end of our study (mid-June) was $P$. pseudodelicatissima occasionally observed living freely in the water column, independent of $C$. socialis. Concentrations of $P$. pseudodelicatissima reached $\sim 6 \times$ $10^{4}$ cells $1^{-1}$.

\section{DISCUSSION}

A major characteristic of both the Pseudo-nitzschia fraudulenta and P. pseudodelicatissima blooms in East Sound is that each had highly non-homogeneous patterns of distribution which resulted in 'hidden' $(P$. fraudulenta), or 'camouflaged' ( $P$. pseudodelicatissima) populations that could easily have been missed by routine monitoring techniques. In the first case their loca- tion within the water column was closely tied to physical oceanographic processes, and in the second to the distribution of Chaetoceros socialis colonies. Further consideration of these issues can contribute to an increased understanding of the ecology of Pseudonitzschia spp.

\section{Critical-scale sampling}

In order to conduct field studies on the dynamics of a taxon, one has to be able to effectively locate the population of interest within the water column. To do so, samples must be collected at a critical scale, where sampling resolution is matched to the scale of the structure. If the vertical distribution of a taxon spans 
many meters, it can be detected by sampling at a fairly coarse resolution (e.g. every 5 or $10 \mathrm{~m}$ ). However, when the majority of cells are concentrated into a thin layer, they are likely to escape detection because they are distributed at a finer scale than that of most traditional sampling grids (Donaghay et al. 1992). The thin layers of Pseudo-nitzschia fraudulenta observed in East Sound had half-heights of $\leq 0.7 \mathrm{~m}$. Had we relied on bottle samples to detect this structure and to resolve the maximum concentration of cells at its peak, it would have required sampling at $0.2 \mathrm{~m}$ intervals, for a total of 600 samples for a single $30 \mathrm{~m}$ profile! We were able to detect the upper water column and near-bottom thin layers of $P$. fraudulenta in East Sound, and estimate their horizontal extent using a combination of high-resolution physical-optical profiles and microscopic examination of discrete samples collected from within the optically detected thin layers. If Pseudonitzschia spp. form similar thin layers in other coastal systems, it is not surprising that conventional bottle sampling does not reliably result in a correlation between the observed distribution of Pseudo-nitzschia spp. and the toxicity of fishes and shellfish.

\section{Physical forcing}

The near-surface bloom of Pseudo-nitzschia fraudulenta observed from May 21 to 25, 1996, abruptly disappeared from the upper water column following a north wind event. Our sampling protocol allowed us to determine that the population was still in East Sound, and was now concentrated in a live, and apparently healthy near-bottom thin layer. Our observations are consistent with the hypothesis that less dense, lowsalinity Fraser River water flowed in over the surface of East Sound. This, in turn drove near-bottom (but not intermediate) water out of the sound, until the water (with its entrained flora) that had been at the depth of the thin layer of the upper water column was now just above the sea floor. Since the P. fraudulenta cells remained within a water mass of $\sim 29.8$ psu throughout the entire period, we conclude that the deep $P$. fraudulenta layer resulted from physical transport of water masses, rather than the sinking of a senescent population. Since buoyant plumes are a common feature in coastal waters, it seems likely that similar events in other systems could rapidly transport Pseudo-nitzschia species to depth, where, if toxic, domoic acid could quickly accumulate in benthic filter-feeders. In such cases, attempts to predict toxicity based on purely physiological considerations (e.g. sinking of a surface bloom following nutrient depletion) would fail.

Rapid displacement of surface water (with its entrained flora) to depth was the result of regional scale physical forcing in the southern part of the Strait of Georgia (Thomson 1981). The reported sequence of events is common in this region, and the resulting near-bottom optical thin layers are a recurrent phenomenon in East Sound (Dekshenieks et al. 2001). In our study, the near-bottom layer was dominated by Pseudo-nitzschia fraudulenta, which appeared to remain healthy and motile despite the very low light (e.g. 1 to $2 \mu \mathrm{mol}$ photons $\mathrm{m}^{-2} \mathrm{~s}^{-1}$ ) at this depth. Very few studies have sampled at the critical scales required to find thin layers, but there is repeated documentation in the literature that Pseudo-nitzschia spp. cells may often reside deep in the water column (e.g. Gran \& Thompson 1930, Forbes \& Denman 1991, Allen in Fryxell et al. 1997, Trainer et al. 1998a).

\section{Deep layers of Pseudo-nitzschia spp.}

Our observations are concordant with the earlier work of Gran \& Thompson (1930). Their study examined the distribution of diatoms in the San Juan archipelago with respect to general circulation patterns and water masses in the region. They discussed the distribution of 'Nitzschia seriata', a name which at that time was used for all Nitzschia species that formed 'stepped' colonies (now called Pseudo-nitzschia). Gran \& Thompson depict the transitory passing of a large population of 'N. seriata', at depth, through the Spieden Channel (Fig. 1) from July 11 to 22, 1928. On July 11, diatoms were limited to the surface layer and the maximum recorded abundance of ' $N$. seriata' was $5 \times 10^{3}$ cells $l^{-1}$. Two days later, $1.6 \times 10^{5}$ cells $1^{-1}$ of ' $N$. seriata' were recorded at $20 \mathrm{~m}$ depth, but only 0 to $10^{3}$ cells $\mathrm{l}^{-1}$ at all other depths $(1,5,10,35,50,100$ and $225 \mathrm{~m})$. Their sampling scale was too coarse to determine whether this was a thin layer sampled only by chance, or part of a broad, subsurface Pseudo-nitzschia spp. maximum. The surface water was several degrees warmer, indicating the presence of a different water mass, interpreted as Fraser River-diluted seawater from the Strait of Georgia. Nearby at Olga, near the mouth of East Sound, ' $N$. seriata' numbers were also greatest at depth: 2.9 and $1.9 \times 10^{5}$ cells $\mathrm{l}^{-1}$ at 10 and $20 \mathrm{~m}$, respectively. A week later, the bloom was not detected at either location. Collectively, this suggests that deep populations of Pseudo-nitzschia spp. are a recurrent phenomenon in the San Juan Islands, perhaps occurring annually in response to hydrographic conditions in early summer related to the seasonal outflow of the Fraser River. Regional hydrography can also influence blooms which are spread throughout much of the water column: the vertical position of a dense, mixedspecies Pseudo-nitzschia bloom in Penn Cove, Whidbey Island (Puget Sound) was strongly influenced by 
the position of buoyancy fronts of less saline water originating from the Skagit River outflow (Trainer et al. 1998a). Forbes \& Denman (1991), examining an extensive data set from British Columbian shelf waters, noted that all but 1 sample in which Pseudo-nitzschia

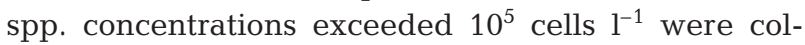
lected at greater than $20 \mathrm{~m}$ depth. In Barkley Sound, on the west coast of Vancouver Island, Taylor \& Haigh (1996) reported intrusions from offshore of Pseudonitzschia spp. at depth, as well as a deep, resident population, which coincided with toxicity of mussels.

In the 1920s and 1930s, W. E. Allen collected an extraordinary phytoplankton data set along the US west coast. Fryxell et al. (1997) reviewed his Pseudonitzschia spp. data, which provided further evidence that healthy Pseudo-nitzschia spp. cells occur in deep layers. Their Fig. 4 depicts Allen's counts at $5 \mathrm{~m}$ intervals at 2 stations off La Jolla, California, in July and August 1927. Concentrations exceeding $10^{5}$ cells l$^{-1}$ were observed as deep as $60 \mathrm{~m}$. On 2 occasions, peak concentrations occurred in a narrow, 5 to $10 \mathrm{~m}$ band. Allen did not have the hydrographic data that would have enabled him to trace water masses. He therefore reached the conclusion that the Pseudo-nitzschia spp. cells were controlling their vertical position in the water column, and unlike a Chaetoceros bloom, which deteriorated at depth, the Pseudo-nitzschia spp. cells maintained their health.

The above observations of deep layers of healthy, non-aggregated colonies are in contrast with those of Dortch et al. (1997), who also noted that Pseudonitzschia spp. could be abundant in bottom waters. These authors documented the sedimentation of Pseudo-nitzschia spp. blooms in the Gulf of Mexico in 1990 and 1991. In these cases, long colonies dissociated into single cells and doublets and sank, with up to $90 \%$ of the material collected in traps being composed of dead cells. The observations of Dortch et al. are consistent with those of Fryxell et al. (1990), who noted that in old cultures, colonies hundreds of cells in length broke apart simultaneously and settled to the bottom as single cells and doublets, which rapidly lost color.

Relative to phytoplankton, the concept of 'deep' depends not so much on the actual water depth as on the depth of light penetration - which will be entirely different in coastal and offshore waters. Nevertheless, there is repeated evidence of Pseudo-nitzschia spp. being found 'deep' in the water column, at very low light levels. If these are indeed viable populations, how are they surviving? The colonies we observed at depth were long and highly motile; hence they were unlikely to have been physiologically resting cells (e.g. Fryxell 1989, McQuoid \& Hobson 1996). Could they have been heterotrophic? Pseudo-nitzschia spp. are raphid, pen- nate diatoms (family Bacillariaceae Ehrenberg 1831). Facultative, and even obligate heterotrophy is well documented (Hellebust \& Lewin 1977, Li \& Volcani 1987) amongst pennates. However, although heterotrophy has been anecdotally reported for Pseudonitzschia spp. (Pan et al. 1996, Stewart et al. 1997), there has been no thorough evaluation of the ability of Pseudo-nitzschia species to persist in low light, or to live heterotrophically in the dark.

\section{Association between Chaetoceros spp. and Pseudo-nitzschia spp.}

Chaetoceros spp. and Pseudo-nitzschia spp. have often been observed to bloom at the same time (W. E. Allen in Fryxell et al.1997). Aggregates of marine snow co-dominated by Chaetoceros spp. and Pseudonitzschia spp. have been reported by Alldredge \& Gotschalk (1989). In contrast to Chaetoceros/Pseudonitzschia aggregates, which are passively formed by the mass flocculation and settling of a diatom bloom (Alldredge \& Gotschalk 1989), our observations show that these genera may actively live in close association with each other. Since Pseudo-nitzschia spp. are pennate diatoms, this is not surprising: Although Pseudonitzschia spp. are considered planktonic, most pennate diatoms live on or in the sediments or attached to a substrate such as another organism, rock, sand grains or pilings (e.g. Round et al. 1990). Other pennate diatoms, especially Nitzschia americana, are commonly observed living on the cell bodies and setae of many Chaetoceros species (Taylor 1980, Rines \& Hargraves 1988, 1990, Fryxell et al. 1990, Hasle \& Syvertsen 1996, Rines: http://thalassa.gso.uri.edu/rines/ ecology/epipred.htm).

Chaetoceros socialis provides a unique micro-environment for this kind of association because it has an unusually complex morphological structure. Individual cells are joined by fusion of the setae of adjacent cells into flexible colonies with specialized terminal valves. Three-quarters of the colony's setae are short and curved to one side of the chain; the remainder are extremely elongate, and are directed in the opposite direction. The commonly observed spherical colony is actually a 'super-colony', composed of numerous individual linear colonies, which are arrayed on the surface of the sphere, much like stitches on a baseball. The elongate setae traverse the interior of the sphere and meet at the center, while the short setae are directed outward, rendering the sphere 'fuzzy' in outline. C. socialis colonies are frequently colonized by many types of protists (Rines \& Hargraves 1988, Sieracki et al. 1998, Rines unpubl. obs.). Long, needle-like 'Nitzschia' living on $C$. socialis have been reported 
by Margalef et al. (1955) and by Taylor (1982). Our repeated observations of $P$. pseudodelicatissima living upon/within $C$. socialis colonies are thus consistent with the biology of raphid, pennate diatoms.

The Chaetoceros socialis-Pseudonitzschia pseudodelicatissima association is of interest for several reasons: (1) By definition, Pseudo-nitzschia spp. are pelagic, colonial diatoms (Hasle 1994, Hasle \& Syvertsen 1996). However, both single cells and chains of $P$. pseudodelicatissima were found living within the C. socialis colonies, suggesting that this taxon may have both unicellular and colonial life-history stages as has previously been suggested for $P$. multiseries and P. subcurvata (Fryxell et al. 1990, 1991). Thus, there is the potential for a Pseudo-nitzschia spp. bloom to develop unnoticed both because it originated as single cells, easily misidentified as non-toxic 'Nitzschia spp.', and because the developing population was camouflaged by the more obvious $C$. socialis colonies. (2) The interior of C. socialis colonies may constitute a microenvironment with conditions different from those in the water column, such that the growth dynamics of Pseudo-nitzschia spp. cells are decoupled from average water column processes. (3) Pseudo-nitzschia spp. are motile only when they have a substrate to glide on. Motility is important for sexual reproduction in Pseudo-nitzschia species, because colonies of different mating types must line up with each other, or clump together (Fryxell et al. 1991, Davidovich \& Bates 1998), and the gametangia require a substrate against which to glide. C. socialis provides a substrate within the water column, which may provide a setting for completion of the life cycle.

\section{Implications}

In order to predict the onset and consequences of Pseudo-nitzschia spp. blooms, we must understand which factors are most important in regulating their distribution through space and over time. To achieve this goal, the correct set of questions must be asked. However, scientific research is often guided by preconceptions and reigning paradigms - we ask questions leading us to look for what we expect to see. It is generally expected that, along with other phytoplankton, Pseudo-nitzschia spp. colonies will be found floating freely in the water column, that they will be located in the 'euphotic zone', and that they will be distributed throughout the surface 'mixed' layer. We questioned several common assumptions, viz (1) that field sampling strategies commonly employed to study phytoplankton in the mixed layer are effective in revealing the distributional patterns of Pseudo-nitzschia spp. populations; (2) that distributional patterns are strictly the result of in situ processes in the water column; and (3) that Pseudo-nitzschia species have life histories typical of other planktonic diatoms. In doing so, we found populations of Pseudo-nitzschia spp. in 3 places in which one would not normally look for them: in an upper water-column thin layer; concentrated in a dense, apparently healthy thin layer, persisting at very low light levels just above the sea floor; and living in association with Chaetoceros socialis colonies. Although growth in response to the nutrient, temperature, light and salinity fields in the upper mixed layer is undoubtedly important in regulating the biomass of a bloom, we found that the vertical distribution of cells was not simply a function of in situ growth processes in the euphotic zone. The deep, dense layer of Pseudonitzschia spp. cells did not result from the sinking of a senescent and/or aggregating population: cells were rapidly advected downward by physical oceanographic events. Although hidden from routine sampling procedures, the Pseudo-nitzschia spp. cells were neither dead nor destroyed, nor had they left the sound. Long, motile colonies suggest a viable population, now in close proximity to filter-feeding shellfish. Might some of the unexplained domoic acid events be related to similar, near bottom thin layers of high cell density?

Pseudo-nitzschia fraudulenta, $P$. pungens and $P$. pseudodelicatissima have been reported to produce low levels of domoic acid (Martin et al. 1990, Rhodes et al. 1996, 1998b, Trainer et al. 1998b, Wekell et al. 1998). Although these taxa do not share the reputation of $P$. australis and $P$. multiseries for causing large-scale domoic acid poisoning events, all 5 are reported from the Puget Sound region. They frequently co-occur, suggesting that species within the genus Pseudonitzschia are ecologically similar. Blooms hidden in thin layers or camouflaged within Chaetoceros socialis colonies pose an additional challenge to domoic acid monitoring efforts, because they imply that (1) a toxicity event can occur, even if Pseudo-nitzschia spp. have not been detected in the water column, and (2) that the toxicity within a thin layer may exceed a threshold value which would not be met if cell concentrations were integrated throughout the water column (e.g. by a net tow).

The extensive coastline of Puget Sound and British Columbia is dominated by fjords and islands. Different water masses, tidal currents and episodic weather systems interact to create complex hydrographic regimes, resulting in the type of physical forcing events that led to the observed Pseudo-nitzschia fraudulenta distributions in East Sound. Similar processes are likely to occur throughout this region as well as along the fjordrich coastlines of Norway, Sweden, Finland, Scotland, Chile and New Zealand. Thus, Pseudo-nitzschia taxa may routinely occur in undetected thin layers, in a 
suite of geographic areas which are extensively utilized by commercial and recreational fisheries as well as by the aquaculture industry. Dense, toxic thin layers have the potential to directly impact shellfish toxicity, to be advected at depth and unnoticed into a new region, or, when mixed back into the euphotic zone, to serve as a large inoculum initiating a sudden surface bloom. Consideration of alternative conceptual frameworks may be critical to the successful development of models predicting the dynamics and impacts of Pseudo-nitzschia spp. blooms.

Acknowledgements. This research was supported by the Office of Naval Research grants N00014-96-0247, N00014-951-0225 and N00014-99-1-0293 to J.E.B.R., P.L.D. and M.M.D. respectively, and by NSF OCE-9108527 awarded to P.L.D. We thank M. McFarland for 1998 cell counts, H. Rines for critical review of the manuscript, and S. Bates for his on-line Pseudonitzschia bibliography (http://www.mar.dfo-mpo.gc.ca/science/ mesd/he/toxins/da.html). P. W. Johnson provided superb assistance with electron microscopy. S. Bates, L. D. Hanson, R. Horner, K. Sellner, V. Trainer and 3 anonymous reviewers contributed information, encouragement and thoughtful suggestions.

\section{LITERATURE CITED}

Alldredge AL, Gotschalk CC (1989) Direct observations of the mass flocculation of diatom blooms: characteristics, settling velocities and formation of diatom aggregates. DeepSea Res 36:159-171

Bates SS (1998) Ecophysiology and metabolism of ASP toxin production. In: Anderson DM, Cembella AD, Hallegraeff GM (eds) Physiological ecology of harmful algal blooms. Springer-Verlag, New York, p 405-426

Bates SS (2001) Domoic-acid-producing diatoms: another genus added! J Phycol 36:978-983

Bates SS and 16 others (1989) Pennate diatom Nitzschia pungens as the primary source of domoic acid, a toxin in shellfish from eastern Prince Edward Island, Canada. Can J Fish Aquat Sci 46:1203-1215

Bates SS, Garrison DL, Horner RA (1998) Bloom dynamics and physiology of domoic-acid-producing Pseudo-nitzschia species. In: Anderson DM, Cembella AD, Hallegraeff GM (eds) Physiological ecology of harmful algal blooms. Spring-Verlag, New York, p 267-292

Bird CJ, Wright JLC (1989) The shellfish toxin domoic acid. World Aquacult 20:40-41

Bjørnsen PK, Nielsen TG (1991) Decimeter scale heterogeneity in the plankton during a pycnocline bloom of Gyrodinium aureolum. Mar Ecol Prog Ser 73:263-267

Cowles T, Donaghay P (1998) Thin layers: observations of small-scale patterns and processes in the upper ocean. Oceanography (Wash) 11:2

Davidovich NA, Bates SS (1998) Sexual reproduction in the pennate diatoms Pseudo-nitzschia multiseries and P. pseudodelicatissima (Bacillariophyceae). J Phycol 34:126-137

Dekshenieks MM, Donaghay PL, Sullivan JM, Rines JEB, Osborn TR, Twardowski MS (2001) Temporal and spatial occurrence of thin phytoplankton layers in relation to physical processes. Mar Ecol Prog Ser 223:61-71

Donaghay PL, Osborn TR (1997) Toward a theory of biological- physical control of harmful algal bloom dynamics and impacts. Limnol Oceanogr 42:1283-1296

Donaghay PL, Rines HM, Sieburth JM (1992) Simultaneous sampling of fine scale biological, chemical, and physical structure in stratified waters. Arch Hydrobiol (Suppl) 36:97-108

Dortch Q, Robichaux R, Pool S, Milsted D, Mire G, Rabalais NN, Soniat TM, Fryxell GA, Turner RE, Parsons ML (1997) Abundance and vertical flux of Pseudo-nitzschia in the northern Gulf of Mexico. Mar Ecol Prog Ser 146:249-264

Forbes JR, Denman KL (1991) Distribution of Nitzschia pungens in coastal waters of British Columbia. Can J Fish Aquat Sci 48:960-967

Fryxell GA (1989) Marine phytoplankton at the Weddell Sea ice edge: seasonal changes at the specific level. Polar Biol 10:1-18

Fryxell GA, Reap ME, Valencic DL (1990) Nitzschia pungens Grunow f. multiseries Hasle: observations on a known neurotoxic diatom. Nova Hedwigia (Beih) 100:171-188

Fryxell GA, Garza SA, Roelke DL (1991) Auxospore formation in an Antarctic clone of Nitzschia subcurvata Hasle. Diatom Res 6:235-245

Fryxell GA, Villac MC, Shapiro LP (1997) The occurrence of the toxic diatom genus Pseudo-nitzschia (Bacillariophyceae) on the West Coast of the USA, 1920-1996: a review. Phycologia 36:419-437

Gran HH, Angst EC (1931) Plankton diatoms of Puget Sound. Publ Puget Sound Mar Biol Stn 7:417-516

Gran HH, Thompson TG (1930) The diatoms and the physical and chemical conditions of the sea water of the San Juan Archipelago. Publ Puget Sound Mar Biol Stn 7:169-204

Hasle GR (1994) Pseudo-nitzschia as a genus distinct from Nitzschia (Bacillariophyceae). J Phycol 30:1036-1039

Hasle GR, Fryxell GA (1995) Taxonomy of diatoms. In: Hallegraeff GM, Anderson, DM, Cembella AD (eds) Manual on harmful marine microalgae. International Oceanographic Commisson, UNESCO, Paris, p 339-364

Hasle GR, Syvertsen EE (1996) Marine diatoms. In: Tomas CR (ed) Identifying marine diatoms and dinoflagellates. Academic Press, Inc, New York, p 5-385

Hasle GR, Lange CB, Syvertsen EE (1996) A review of Pseudonitzschia, with special reference to the Skagerrak, North Atlantic, and adjacent waters. Helgol Meeresunters 50: 131-175

Hellebust JA, Lewin J (1977) Heterotrophic nutrition. In: Werner D (ed) The biology of diatoms. University of California Press, Berkeley, p 169-197

Horner RA, Garrison DL, Plumley FG (1997) Harmful algal blooms and red tide problems on the U.S. west coast. Limnol Oceanogr 42:1076-1088

Li CW, Volcani BE (1987) Four new apochlorotic diatoms. Br Phycol J 22:375-382

Margalef R, Durán M, Saiz F (1955) El fitoplancton de la ría de Vigo de enero de 1953 a marzo de 1954. Invest Pesq (Barc) 2:85-129

Martin JL, Haya K, Burridge LE, Wildish DJ (1990) Nitzschia pseudodelicatissima - a source of domoic acid in the Bay of Fundy, eastern Canada. Mar Ecol Prog Ser 67:177-182

McQuoid MR, Hobson LA (1996) Diatom resting stages. J Phycol 32:889-902

Pan Y, Subba Rao DV, Mann KH (1996) Acclimation to low light intensity in photosynthesis and growth of Pseudonitzschia multiseries Hasle, a neurotoxigenic diatom. J Plankton Res 18:1427-1438

Rattray MJ (1964) Some aspects of the dynamics of circulation in fjords. In: Lauff G (ed) Estuaries. American Association for the Advancement of Science, Washington, DC, p 52-62 
Rhodes L, White D, Syhre M, Atkinson M (1996) Pseudonitzschia species isolated from New Zealand coastal waters: domoic acid production in vitro and links with shellfish toxicity. In: Yasumoto $\mathrm{T}$, Oshima $\mathrm{Y}$, Fukuyo Y (eds) Harmful and toxic algal blooms. International Oceanographic Commission UNESCO, Paris, p 155-158

Rhodes L, Scholin C, Garthwaite I, Haywood A, Thomas A (1998) Domoic acid producing Pseudo-nitzschia species educed by whole cell DNA probe-based and immunochemical assays. In: Reguera B, Blanco J, Fernández ML, Wyatt $\mathrm{T}$ (eds) Harmful algae. Xunta de Galicia and Intergovernmental Oceanographic Commission, UNESCO, Santiago de Compostela, Spain, p 274-277

Rines JEB, Hargraves PE (1988) The Chaetoceros Ehrenberg (Bacillariophyceae) flora of Narragansett Bay, Rhode Island, U.S.A. Bibl Phycol 79:1-196

Rines JEB, Hargraves PE (1990) Morphology and taxonomy of Chaetoceros compressus var. hirtisetus var. nova, with preliminary consideration of closely related taxa. Diatom Res 5:113-127

Round FE, Crawford RM, Mann DG (1990) The diatoms. Cambridge University Press, Cambridge

Scholin CA and 25 others (2000) Mortality of sea lions along the central California coast linked to a toxic diatom bloom. Nature 403:80-84

Sieracki ME, Gifford DJ, Gallaher SM, Davis CS (1998) Ecology of a Chaetoceros socialis bloom on Georges Bank: distribution, microbial associations, and grazing losses. Oceanography (Wash) 11:30-35

Simonsen R (1974) The diatom plankton of the Indian Ocean Expedition of R/V 'Meteor' 1964-1965. Meteor Forschergeb Reihe D Biol 19:1-107

Stewart JE, Marks LJ, Wood CR, Risser SM, Gray S (1997) Symbiotic relations between bacteria and the domoic acid producing diatom Pseudo-nitzschia multiseries and the capacity of these bacteria for gluconic acid/gluconolactone formation. Aquat Microb Ecol 12:211-221

Editorial responsibility: Barry and Evelyn Sherr (Contributing Editors), Corvallis, Oregon, USA
Taylor FJR (1980) Basic biological features. In: Morris I (ed) The physiological ecology of phytoplankton. University of California Press, Berkeley, p 3-55

Taylor FJR (1982) Symbioses in marine microplankton. Ann Inst Océanogr 58:61-90

Taylor FJR, Haigh R (1996) Spatial and temporal distributions of microplankton during the summers of 1992-1993 in Barkley Sound, British Columbia, with emphasis on harmful species. Can J Fish Aquat Sci 53:2310-2322

Taylor FJR, Haigh R, Sutherland TF (1994) Phytoplankton ecology of Sechelt Inlet, a fjord system on the British Columbia coast. Mar Ecol Prog Ser 103:151-164

Thomson RE (1981) Oceanography of the British Columbia coast. Can Spec Publ Fish Aquat Sci 56:1-291

Trainer VL, Adams NG, Bill BD, Anulacion BF, Wekell JC (1998a) Concentration and dispersal of a Pseudo-nitzschia bloom in Penn Cove, Washington, USA. Nat Toxins 6: $113-126$

Trainer VL, Wekell JC, Horner RA, Hatfield CL, Stein JE (1998b) Domoic acid production by Pseudo-nitzschia pungens. In: Reguera B, Blanco J, Fernández ML, Wyatt $\mathrm{T}$ (eds) Harmful algae. Xunta de Galicia and Intergovernmental Oceanographic Commission, UNESCO, Santiago de Compostela, Spain, p 337-340

Twardowski MS, Donaghay PL (2001) Separating in situ and terrigenous sources of absorption by dissolved materials in coastal waters. J Geophys Res 106:2545-2560

Twardowski MS, Sullivan JM, Donaghay PL, Zaneveld JRV (1999) Microscale quantification of the absorption by dissolved and particulate material in coastal waters with an ac-9. J Atmos Oceanic Technol 16:691-707

Wekell JC, Horner RA, Postel JR, Hatfield CL, Ross AM, Trainer VL (1998) In situ domoic acid levels in Pseudonitzschia cells off the Washington state coast in July 1996 In: Reguera B, Blanco J, Fernández ML, Wyatt T (eds) Harmful algae. Xunta de Galicia and Intergovernmental Oceanographic Commission, UNESCO, Santiago de Compostela, Spain, p 235-236

Submitted: March 28, 2000; Accepted: April 2, 2001 Proofs received from author(s): November 15, 2001 